\title{
Reprogramming of rye rDNA in triticale during microsporogenesis
}

\author{
M. Silva, A. Queiroz, N. Neves, A. Barão, A. Castilho, \\ L. Morais-Cecílio \& W. Viegas
}

Received 14 February 1995; received in revised form 22 May 1995

Accepted for publication by J. S. (Pat) Heslop-Harrison 8 June 1995

\begin{abstract}
To test the hypothesis that interspecific genomic and chromosome interactions leading to nucleolar dominance could be reprogrammed in meiosis, we compared the expression of distinct nucleolar organizing region (NOR) loci in hexaploid triticale root tip meristematic cells, pollen mother cells and young pollen grains. Interphase and metaphase cells were silver stained to quantify nucleoli and active NOR loci respectively. A marked difference in the ribosomal RNA gene activity of each locus was observed when different types of cells were compared: in somatic and pollen mother cells, rRNA gene activity was mainly restricted to major wheat NORs (1B and $6 B$ ) with only a small contribution from rye NORs (1R). In contrast, in young pollen grains, all NORs present, including the 1R NORs, were consistently active. The expression of all NORs just after meiosis is considered to be a consequence of meiotic reprogramming of rye origin rDNA. Gene reprogramming mediated by the resetting of methylation patterns established early in embryogenesis is suggested to be responsible for the differential expression of the NORs of rye origin in distinct developmental stages of triticale.
\end{abstract}

Key words: meiotic reprogramming, microspores, nucleolar dominance, rDNA expression, rye NOR

\section{Introduction}

The phenomenon of nucleolar dominance has been widely reported in interspecific plant or animal hybrids through the observation that ribosomal genes of one species are transcriptionally dominant over the ribosomal genes of other species (Reeder 1985). Nucleolar dominance has been extensively studied in some hybrids of wheat [Triticum aestivum (L.) em Thell] and its relatives For example, in wheat $\times$ Aegilops umbellulata Zhuk hybrids, most of the nucleolar activity comes from the Ae. umbellulata genes, while the expression of wheat rRNA genes is minimal (Martini et al. 1982). Similarly, the activity of the nucleolar organizing region (NOR) of chromosome 1 of rye (Secale cereale L.) is undetectable by silver staining in wheat $x$ rye F1 hybrids and in $\times$ Triticosecale Whittmack (Cermeño et al. 1984, Lacadena et al. 1984, Vieira et al. 1990); however, the occasional 1R NOR decondensation detected by in situ hybridization with a probe for rye rDNA spacer indicates that the activity of these genes is low (Appels et al. 1986, Gustafson et al. 1988).

Nucleolar dominance has also been detected in hexaploid wheat cv. Chinese Spring (Flavell \& O'Dell 1976, Martini \& Flavell 1985), in which two major NORs have been located on chromosomes $1 \mathrm{~B}$ and $6 \mathrm{~B}$ and two minor NORs on chromosomes 1A and 5D (Crosby 1957, Darvey \& Driscoll 1972, Viegas \& Mello-Sampayo 1975, Flavell \& O'Dell 1976, Hutchinson \& Miller 1982, Martini \& Flavell 1985); a fifth NOR on chromosome 7D has recently been identified by in situ hybridization (Mukai et al. 1991). A clear correlation between nucleolar activity, the length of rDNA intergenic spacers and DNA methylation of the regulatory sequences has been observed, suggesting that these play a major role in nucleolar dominance (Flavell et al. 1988, Sardana et al. 1992). Vieira et al. (1990), Heslop-Harrison (1990) and Neves et al. (1995) have also shown that in wheat $x$ rye F1 hybrids and in triticales rRNA genes of rye origin can be activated by treatment with 5-azacytidine, the potent inhibitor and false substrate for DNA methylases, suggesting that the phenomenon of nucleolar dominance observed in these plants is also mediated by rDNA methylation.

It is known that both in animals and in plants some DNA methylation patterns are modified during meiosis (Holliday 1987, Monk 1987, Neves et al. 1992). We suggested that nucleolar dominance in triticale could also be reprogrammed in meiosis through the alteration of rDNA methylation patterns established in somatic

M. Silva (corresponding author), A. Queiroz, N. Neves, A. Barão, A. Castilho, L. Morais-Cecilio and W. Viegas are at the Departamento de Botânica e Engenharia Biológica, Instituto Superior de Agronomia, Tapada da Ajuda, P-1399 Lisboa Codex, Portugal. Tel: (+351) 1363 8161; Fax: (+351) 1363 5031. 
cells during early stages of seed development (Castilho et al. 1995). In the present study we evaluate the expression of NOR loci in different cell types of hexaploid triticale by using the silver staining procedure for the quantification of nucleoli in interphase cells and active NORs on metaphase chromosomes.

\section{Materials and methods}

Cell nucleolar activity was analysed in hexaploid triticale, $6 \times$ Triticosecale Wittmack, cvs. Drira and Juanilho (genome designation AABBRR), at the following developmental stages: meristematic root tip cells (somatic cells), premeiotic interphase cells and metaphase I cells (pollen mother cells) and tetrad and pollen grains at first mitotic division (young pollen grains).

To evaluate nucleolar activity through the analysis of the number of nucleoli in interphase cells and by the quantification of AgNORs in metaphase cells we used the silver nitrate impregnation technique, as it has already been clearly demonstrated that usually only NORs functionally active during the preceding interphase are stained on mitotic chromosomes (Hubbel 1985, Jiménez et al. 1988).

Seeds were germinated in the dark in Petri dishes on filter paper soaked with distilled water for 2-3 days at $24^{\circ} \mathrm{C}$. Root tips ( $1 \mathrm{~cm}$ long) were excised and immersed in a $0.05 \%(\mathrm{w} / \mathrm{v})$ colchicine solution for $4 \mathrm{~h}$, rinsed with distilled water, cold treated for $24 \mathrm{~h}$ and finally fixed in FAA $[37 \%(v / v)$ formaldehyde-glacial acetic acid- $50 \%$ $(\mathrm{v} / \mathrm{v})$ ethanol in a 1:1:18 $(\mathrm{v} / \mathrm{v} / \mathrm{v})$ proportion] for at least 2-3 days at $4^{\circ} \mathrm{C}$ before use. Plants were further grown in the greenhouse until the emergence of the flag leaf, when spikes were collected and one anther of each floret from each spikelet was excised and analysed to select those at the appropriate stages. To obtain arrested metaphase cells at the first mitotic pollen division, plants with anthers at the end of the first pollen grain interphase were maintained at $4^{\circ} \mathrm{C}$ for $24 \mathrm{~h}$ with continuous light. After the selection of florets the anthers at the desired developmental stages were fixed in FAA for 2-3 days at $4^{\circ} \mathrm{C}$ before staining.

Root tips and anthers were thoroughly washed in distilled water to remove the fixative solution and were then placed in a $20 \%(\mathrm{w} / \mathrm{v})$ silver nitrate solution adjusted to $\mathrm{pH} 5.3-5.6$ and incubated at $60^{\circ} \mathrm{C}$ in the dark overnight. For the staining of young pollen grains at the tetrad stage and at the first pollen grain division, anthers were immersed in $0.01 \mathrm{M}$ borate buffer ( $\mathrm{pH} 9.2$ ) for $4 \mathrm{~h}$ after washing and immersed overnight at $60^{\circ} \mathrm{C}$ in a $40 \%(\mathrm{w} / \mathrm{v})$ silver nitrate solution in $0.1 \%(\mathrm{v} / \mathrm{v})$ 'Citowett', used to allow a better impregnation. After staining the material was washed several times and transferred to a $10 \%(\mathrm{v} / \mathrm{v})$ formaldehyde-1\% (w/v) hydroquinone $(1: 1, \mathrm{v} / \mathrm{v})$ solution for approximately $5 \mathrm{~min}$ in order to develop the silver nitrate. After a second wash, the material was squashed in a drop of acetic acid $45 \%(\mathrm{v} / \mathrm{v})$.

\section{Nucleoli and ST-NORs frequencies}

For each developmental stage, the frequency of interphase cells with different numbers of nucleoli and of metaphase cells with distinct numbers of AgNORs was recorded from at least three plants. For each stage and per plant analysed, 350 interphase cells and 50 metaphase cells were scored, except that for young pollen grain first mitosis 32 and 25 cells were scored in cvs. Drira and Juanilho respectively. In this study only subterminal silver-stained NORs (ST-NORs), the major NORs located on chromosomes $1 B, 6 B$ and $1 R$, were considered.

\section{Results}

The frequencies of interphase cells with different numbers of nucleoli and of metaphases with distinct number of Ag-ST-NORs are shown in Tables 1 and 2 respectively.

Table 1. Frequency of interphase cells with different numbers of nucleoli in distinct cell types of $6 \times$ Triticosecale cvs. Drira and Juanilho

\begin{tabular}{|c|c|c|c|c|c|c|c|}
\hline \multirow[t]{2}{*}{ Genotype } & \multirow[t]{2}{*}{ Cell types ${ }^{a}$} & \multicolumn{6}{|c|}{ Frequency of interphase cells with different number of nucleoli $(\%)^{b}$} \\
\hline & & 1 & 2 & 3 & 4 & 5 & 6 \\
\hline \multirow[t]{3}{*}{$6 \times$ Triticosecale cv. Drira } & $\mathrm{RT}$ & 19.58 & 35.01 & 32.93 & 11.79 & 0.69 & 一 \\
\hline & PMC & 17.88 & 49.23 & 29.47 & 3.09 & 0.33 & - \\
\hline & YP & 25.54 & 66.31 & 6.75 & 1.40 & - & 一 \\
\hline \multirow[t]{3}{*}{$6 \times$ Triticosecale cv. Juanilho } & RT & 17.69 & 40.70 & 29.20 & 11.89 & 0.52 & 一 \\
\hline & PMC & 22.58 & 49.43 & 25.17 & 2.82 & - & - \\
\hline & $\mathrm{YP}$ & 18.49 & 75.76 & 4.96 & 0.79 & - & 一 \\
\hline
\end{tabular}

${ }^{2} \mathrm{RT}$, root tip interphase cells; $\mathrm{PMC}$, pollen mother cells (premeiotic interphase); YP, young pollen grains (tetrad stage).

${ }^{b} A$ total of 350 interphase cells were scored per cell type in each cultivar. 


\section{Silva et al.}

Table 2. Frequency of metaphase cells with different numbers of Ag-subterminal-NORs (Ag-ST-NORs) in distinct cell types of $6 \times$ Triticosecale cvs. Drira and Juanilho

\begin{tabular}{lccccccc}
\hline Genotype & Ceil types $^{a}$ & \multicolumn{5}{c}{ Frequency of metaphase cells with different number of NORs $(\%)^{\mathrm{b}}$} \\
\cline { 3 - 8 } & & 1 & 2 & 3 & 4 & 5 & 6 \\
\hline $6 \times$ Triticosecale cv. Drira & RT & - & - & 8.49 & 85.62 & 2.62 & 3.27 \\
& PMC & - & 6.67 & 1.33 & 86.66 & 0.67 & 4.67 \\
& YP & - & - & 100.0 & - & - & - \\
$6 \times$ Triticosecale cv. Juanilho & RT & - & 1.82 & 8.49 & 86.06 & 2.42 & 1.21 \\
& PMC & - & 12.15 & 5.61 & 75.70 & 0.93 & 5.61 \\
& YP & - & 4.00 & 96.00 & - & - & - \\
\hline
\end{tabular}

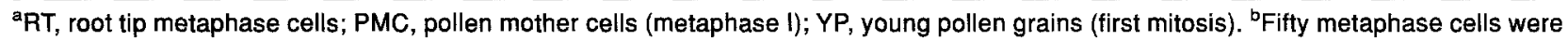
scored per cell type in each cultivar except that for YP 32 and 25 cells were scored for cvs. Drira and Juanilho respectively.

Meristematic root tip cells

In both triticale cvs. Drira and Juanilho, the large majority of cells showed four Ag-ST-NORs on wheat chromosomes $1 \mathrm{~B}$ and $6 \mathrm{~B}$, with a low frequency of cells with five or six Ag-ST-NORs (5.8\% in cv. Drira and 3.6\% in $\mathrm{cv}$. Juanilho). In cells with more than four major NORs, four presented the typical dark-brown staining while the additional ones showed a light-brown and very faint stain (Figure 1a). Through chromosome morphology, size and position of the NORs, this faint pair of Ag-ST-NORs was identified as the chromosome 1R NORs. It is well established that there is usually a direct correlation between the intensity of silver staining of NORs and the level of their transcriptional activity during the preceding interphase (Hofgartner et al. 1979, Baldini et al. 1988, Sumner 1990). Thus, we have detected the residual activity of rye rRNA genes in the presence of wheat genomes through silver staining, which has been previously detected only by in situ hybridization (Appels et al. 1986, Gustafson et al. 1988).

\section{Pollen mother cells}

In both triticale cultivars analysed, a high proportion of cells showed only four NORs $(86.7 \%$ in cv. Drira and $75.7 \%$ in cv. Juanilho; Figure 1b). As in root tip cells, some cells with one or two faint additional Ag-STNORs, probably on chromosomes $1 \mathrm{R}$, were observed (5.3\% in cv. Drira and $6.5 \%$ in cv. Juanilho), indicating that wheat nucleolar dominance leading to a preferential inactivation of rye origin $\mathrm{rDNA}$ is maintained until the interphase preceding meiosis.

\section{Young pollen grains}

A very high frequency of cells showed three subterminal NORs ( $100 \%$ in cv. Drira and $96 \%$ in cv. Juanilho; Figure 1c), indicating the full expression of $1 \mathrm{R}$ NOR along with the activity of $1 \mathrm{~B}$ and $6 \mathrm{~B}$ NORs.

The activity of the $1 R$ NORs in young pollen grains is further confirmed by the observation that, while both root tips and pollen mother cells never attained the potential maximum nucleoli number, several young pollen grains showed four nucleoli $(1.4 \%$ in cv. Drira and $0.8 \%$ in $\mathrm{cv}$. Juanilho; Figure 1d), reflecting the activity of all the NORs present in these haploid cells $(1 \mathrm{~B}, 6 \mathrm{~B}, 1 \mathrm{~A}$ and $1 \mathrm{R})$.

\section{Discussion}

The mechanism of intraspecific nucleolar dominance in wheat has been presented by Flavell and collaborators, who found that rRNA gene activity depends on the structure of intergenic spacers and DNA methylation. (Flavell et al. 1988, Sardana et al. 1992). The implication of distribution of methylated cytosines in determining which genes are available for transcription has also been proposed for the amphiplasty phenomenon in wheat $\times$ rye F1 hybrids (Vieira et al. 1990) and in triticale (Heslop-Harrison 1990, Neves et al. 1995).

In this work we have found that nucleolar dominance is erased between pollen mother cells and young pollen grain, the $1 \mathrm{R}$ NOR becoming active in the later stage analysed. As meiotic reprogramming can be mediated through modification of methylation state, initially proposed for animals by Holliday (1984), we suggest the occurrence during meiosis of a resetting of rDNA methylation patterns, allowing the efficient transcription of rye rRNA genes in young pollen grains.

Evidence suggests that rRNA genes are in excess in most plants (Flavell et al. 1986) and nucleolar dominance is one process that the cell may use to regulate selectively the number of active rRNA genes. The expression of all NOR loci observed just after meiosis in triticale young pollen grains can reflect (i) a wide genomic reprogramming so that the genes and expression patterns in young embryos represent their early progenitors' condition or (ii) a specific ribosomal gene activation related to particular cell requirements or different ribosome processing/maturation immediately after meiosis. It seems likely that regulatory mechanisms that act over the lifetime of a plant, such as 


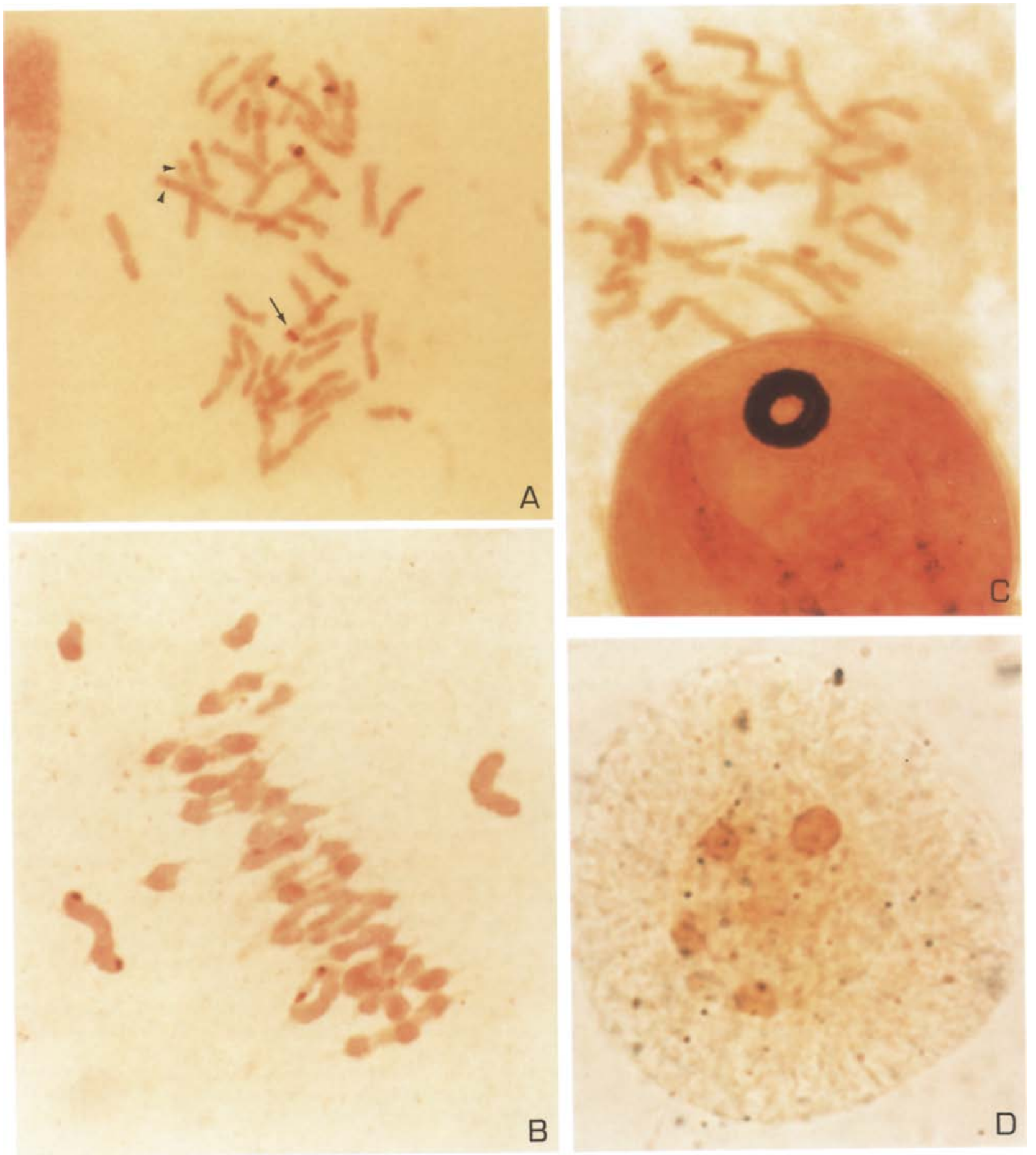

Figure 1. Cells from different developmental stages of hexaploid triticale after silver staining. a Root tip metaphase cell of triticale cv. Drira with four strongly stained wheat ST-NORs (example arrowed) and additional very faintly stained ST-NORS belonging to chromosome pair 1R (arrowhead). b Pollen mother cell at metaphase I from triticale cv. Juanilho with four silver-stained major NORs on bivalents $1 \mathrm{~B}$ and $6 \mathrm{~B}$. $\mathrm{c}$ First pollen grain mitosis of triticale cv. Drira with three subterminal STNORs $(1 \mathrm{~B}, 6 \mathrm{~B}$ and $1 \mathrm{R})$. d Young microspore of triticale $\mathrm{cV}$. Juanilho at tetrad stage showing four silver-stained nucleoli, corresponding to the full expression of all NORs present (1A, 1B, 6B and 1R). 


\section{Silva et al.}

nucleolar dominance and the reprogramming of the genes during meiosis, may have important consequences for evolution and the flexibility of new hybrid genotypes.

\section{Acknowledgements}

This work was supported by a grant from the Junta National de Investigação Científica e Tecnológica, Portugal. We are very grateful to Dr J.S. Heslop-Harrison for critically reviewing the manuscript.

\section{References}

Appels R, Moran LB, Gustafson JP (1986) The structure of DNA from the rye (Secale cereale) NOR R1 locus and its behaviour in wheat backgrounds. Can J Genet Cytol 28: 673685.

Baldini A, Felli MP, Ravenna L et al. (1988) Differential ribosomal gene responsiveness to human growth hormone is visualised by selective silver staining. Cytogenet Cell Genet 47: 22-25.

Castilho, A, Queiroz, A, Neves, $\mathrm{N}$ et al. (1995) The developmental stage of inactivation of rye origin rRNA genes in the embryo and endosperm of wheat-rye F1 hybrids. Chrom Res 3: 169-174.

Cermeño MC, Orelana J, Santos JL, Lacadena JR (1984) Nucleolar organizer activity in wheat, rye and derivatives analysed by a silver staining procedure. Chromosome 89: 370-376.

Crosby AR (1957) Nucleolar activity of lagging chromosomes in wheat. Am J Bot 44: 813-822.

Darvey NL, Driscoll CJ (1972) Nucleolar behaviour in Triticum. Chromosoma 36: 131-139.

Flavell RB, O'Dell M (1976) Ribosomal rRNA genes on homoeologous chromosomes of groups 5 and 6 in hexaploid wheat. Heredity 37: 377-385.

Flavell RB, O'Dell M, Thompson WF et al. (1986) The differential expression of ribosomal RNA genes. Phil Trans $R$ Soc Lond $B$ 314: 385-397.

Flavell RB, O'Dell M, Thompson WF (1988) Regulation of cytosine methylation in ribosomal DNA and nucleolus organiser expression in wheat. J Mol Biol 204: 523-534.

Gustafson JP, Dera AR, Petrovic S (1988) Expression of modified rye ribosomal genes in wheat. Proc Natl Acad Sci USA 85: 3943-3945.

Heslop-Harrison JS (1990) Gene expression and parental dominance in hybrid plants. Development (Suppl) 21-28.

Hofgartner F J, Krone W, Jain K (1979) Correlated inhibition of ribosomal RNA synthesis and silver staining by actinomycin D. Hum Genet 47 329-333.
Holliday R (1984) The biological significance of meiosis. In Evans C, Dickenson H, eds. Controlling Events in Meiosis. London: Society for Experimental Biology, pp 381-394.

Holliday R (1987) Ageing: X-chromosome reactivation. Nature 327: $661-662$.

Hubbell HR (1985) Silver staining as an indicator of active ribosomal genes. Stain Technol 60: 285-294.

Hutchinson J, Miller T (1982) The nucleolar organisers of tetraploid and hexaploid wheats revealed by in situ hybridization. Theor Appl Genet 61: 285-288.

Jiménez R, Burgos M, Diaz de la Guardia R (1988) A study of the Ag-staining significance in mitotic NORs. Heredity 60: 125-127.

Lacadena JR, Cermeño MC, Orellana J, Santos JL (1984) Evidence for wheat-rye nucleolar competition (amphiblasty) in triticale by silver staining procedure. Theor Appl Genet 67: 207-213.

Martini G, Flavell RB (1985) The control of the nucleolus volume in wheat, a genetic study of three developmental stages. Heredity 54: 111-120.

Martini G, O'Dell M, Flavell RB (1982) Partial inactivation of wheat nucleolus organizers by the nucleolus organizer chromosomes of Aegilops umbellulata. Chromosoma 84: $687-700$.

Monk M (1987) Genomic imprinting: memories of mother and father. Nature 328: 203-204.

Mukai Y, Endo TR, Gill BS (1991) Physical mapping of the 18S.26S rRNA multigene family in common wheat: identification of a new locus. Chromosoma 100: 71-78.

Neves N, Barão A, Castilho A et al. (1992) Influence of DNA methylation of rye B-chromosome non-disjunction. Genome 35: $650-652$.

Neves, N, Viegas, W, Heslop-Harrison, J (1995) The study of rye rDNA expression in the presence of wheat genomes after the incorporation of 5-azacytidine in different periods of seed maturation. Theor Appl Genet (in press).

Reeder RH (1985) Mechanisms of nucleolar dominance in animals and plants. J Cell Biol 101: 2013-2016.

Sardana R, O'Dell M, Flavell RB (1992) Correlation between the size of the intergenic regulatory region, the status of cytosine methylation of rRNA genes and nucleolar expression in wheat. Mol Gen Genet (in press).

Sumner AT (1990) Nucleolar organisers (NORs). In: Chromosome Banding. London: Unwin Hyman, pp 187-205.

Thompson WF, Flavell RB (1988) DNase I sensitivity of ribosomal RNA genes in chromatin and nucleolar dominance in wheat. $J$ Mol Biol 204: 535-548.

Viegas WS, Mello-Sampayo T (1975) Nucleolar organization on the genus Triticum. Broteria (Ciências Naturais). 44: 121133.

Vieira R, Queiroz A, Morais L et al. (1990) 1R chromosome nucleolus organizer region activation by 5-azacytidine in wheat $\times$ rye hybrids. Genome 33: 707-712. 